\title{
DEVELOPMENT OF A VIRTUAL 3D-SIMULATOR OF THE FEED PELLETING TECHNOLOGICAL PROCESS
}

\author{
N. Shcherbakov ${ }^{1}$, F. Trishyn ${ }^{2}$ \\ ${ }^{1,2}$ Odessa National Academy of Food Technologies, Odessa, Ukraine
}

Copyright (C) 2014 by author and the journal -Automation technological and business - processesll. This work is licensed under the Creative Commons Attribution International License (CC BY). http://creativecommons.org/licenses/by/4.0/

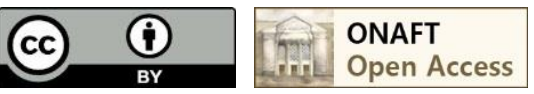

Abstract: The process of developing a virtual 3D simulator of the process of granulation of mixed fodders is considered. The consequences of errors in the operation of press granulator operators are considered. The difficulties associated with the training of high-tech and expensive equipment operators are described. The necessity and described difficulties of acquiring practical skills of working with such equipment at the training stage are substantiated. It is argued the need to introduce computer simulators in educational institutions in order to improve the quality of the acquired knowledge, form a complex decision-making skill for future operators of technological processes. The results of a survey on improving the efficiency of management of technological processes after the introduction of simulators at enterprises are considered. The data of the simulator market and its forecasts for 2017 by regions and types of the interface used are presented. The conclusion is drawn about the growing popularity of simulators based on the 3D interface. The advantage of using the $3 D$ interface with respect to the $2 D$ interface is substantiated. The types of immersion in the learning environment in various simulator interfaces are considered. The vulnerabilities of the $3 D$ simulator are noted. The goal is to develop a $3 D$ simulator for a press granulator operator. A solution of a set of tasks is proposed to achieve this goal. The plan for creating a simulator was developed. A detailed consideration of the development stages of the simulator is given. The possibilities of using the simulator being developed are considered. The possibility of developing a simulator of emergency situations is described. The relevance of this development is justified.

Keywords: Computer simulator, virtual simulator, 3D simulator, simulator of technological process of pelleting feed.

Every year the enterprises increases the share of high-tech and expensive equipment, which is characterized by high complexity, energy consumption and accident which can cause great economic losses. Such equipment, of course, is the pellet mill. Operator errors when working with it can lead to serious consequences: potential accidents, reduce product quality, downtime and other economic losses that are comparable in scale with the losses from accidents. To work with such equipment need specially trained, skilled operators, which will be responsible for the consequences of their decisions in the process. Thus, more pressing is task of training operators in process control system [1]. However, even with a high level of theoretical training, the student after graduation is experiencing some difficulties in the transition to practice directly in the enterprise. To solve this problem it is necessary during training to acquire practical skills. But within the framework of educational process can be a number of reasons that will prevent this such as:

- the inability of providing students with materials, tools, and other means;

- the high cost of materials for the practical work, which hinders their mass application;

- high transience of studied processes that prevent the student effectively capture and reflect the observed results.

One solution to these problems may be the development of virtual trainer-simulators of technological process. The main objective of such trainer-simulators is the formation of the complex skill of decision-making that is based on the ability to simulate the dynamic response of the object and the control system on an arbitrary control actions of the operator. Ie in fact, the simulators are the same software process modeling in dynamic regime with a mandatory requirement of the provision of real time. The interactivity of these simulators allows training in conditions close to real. Application of mathematical models of real equipment, processes, various types of emergency and abnormal situations makes it possible to repeatedly reproduce certain modes of operation, without any resources of real equipment and without compromising personnel and products.

Implementation of this approach became possible due to the rapid development and reduction in price of computer technology and progress in the field of creation of virtual reality. Based on these technologies developed many simulators for military applications, medicine, various industries, etc [2].

The effectiveness of simulators has been confirmed by many surveys, one of which was taken in Norway in 2012 . During the surveys were received 99 responses from enterprises owned by 11 companies. Among the respondents $36 \%$ were engineers, $31 \%$ operators, $20 \%$ instructors, $13 \%$ managers [2]. 
From the point of view of the operators, the simulators:

\section{http://atbp.onaft.edu.ua/}

- improves the understanding of the process and the ability to manage them safely $(84 \%)$;

- strengthens the ability to cope with faults (81\%);

- gives confidence and convenience in the daily work $(71 \%)$;

- Instructors, engineers and managers;

- acceleration of start (79\%);

- reduction of operational risks and strengthen the integrity of TP $(72 \%)$;

- increasing the productivity of the plants $(62 \%)$.

More than $80 \%$ of survey participants stated improving the efficiency of operators (marked significant), the average improvement is estimated at $31 \%$ (tab. 1).

Table 1 - Improving the effectiveness of the training level of operators

\begin{tabular}{|c|c|c|c|c|c|}
\hline Not increased & $\begin{array}{c}\text { Slightly } \\
\text { increased } \\
(<10 \%)\end{array}$ & $\begin{array}{c}\text { Is much } \\
(10 \ldots 30 \%)\end{array}$ & $\begin{array}{c}\text { Strongly } \\
(30 \ldots 50 \%)\end{array}$ & $\begin{array}{c}\text { Very much } \\
(50 \ldots 75 \%)\end{array}$ & $\begin{array}{c}\text { is Extremely } \\
\text { strong } \\
(75 \ldots 100 \%)\end{array}$ \\
\hline $4 \%$ & $16 \%$ & $39 \%$ & $23 \%$ & $9 \%$ & $9 \%$ \\
\hline
\end{tabular}

The need for virtual machines increases more and more. This is evidenced by the forecast of market simulators, 2017 (tab. 2) [4].

Table 2 - Market forecast of simulators in 2017, with market share by regions

\begin{tabular}{|l|c|c|c|c|c|}
\hline Region & $\begin{array}{c}2012, \\
\text { million USA }\end{array}$ & $2012, \%$ & $\begin{array}{c}2017, \\
\text { million USA }\end{array}$ & $2017, \%$ & CAGR, \% \\
\hline Europe, middle East, Africa & 172,7 & 35,6 & 254,0 & 33,4 & 8,0 \\
\hline North America & 163,3 & 33,6 & 242,3 & 31,9 & 8,2 \\
\hline Asia & 124,8 & 25,7 & 227,1 & 29,9 & 12,7 \\
\hline Latin America & 24,9 & 5,1 & 36,4 & 4,8 & 7,8 \\
\hline In total & 458,8 & 100 & 759,8 & 100 & 9,4 \\
\hline
\end{tabular}

As you can see, the total market volume in 2012 was $\$ 458,8$ million and in 2017 should reach $\$ 759,8$ million, with an average annual growth of $9.4 \%$.

The forecast of growth by type of interface can be seen from tab. 3 .

Table 3 - Market forecast of simulators in 2017 by the types of the interface

\begin{tabular}{|l|c|c|c|c|c|}
\hline & $\begin{array}{c}2012, \\
\text { million } \\
\text { USA }\end{array}$ & $2012, \%$ & $\begin{array}{c}2017, \\
\text { million USA }\end{array}$ & $2017, \%$ & CAGR, \% \\
\hline Traditional 2D interfaces & 382,4 & 78,7 & 548,7 & 78,3 & 7,5 \\
\hline 3D interfaces & 31,0 & 6,4 & 52,8 & 7,5 & 11,2 \\
\hline Virtual reality & 25,6 & 5,3 & 42,5 & 6,1 & 10,7 \\
\hline Other & 46,8 & 9,6 & 56,9 & 8,1 & 4 \\
\hline
\end{tabular}

As you can see, systems with 3D interfaces and virtual reality will occupy an increasing share of the market. This is due to the many advantages of 3D over traditional interface. 3D visualization gives a better sense of immersivness: presence, immersion in the environment. According to Ernest Adams, immersion should be distinguished in the following types [5]:

- tactical - execution of local operations, requiring skill;

- strategic - more intelligent, due to the solution of mental problems (choosing the right solution among the wide range of possibilities);

- narrative - deep dive into the script;

- emotional - experience the emotions caused by involvement in a simulated situation;

- touch - the sensation of being in a three-dimensional environment;

- spatial - a sense of dimensions of the space and objects;

- psychological - operator identified with the actors, who manage the TP.

Many elements of the immersion already present in the training interfaces. In tab. 4 they are distributed according to the dimension and type of presentation.

To two-dimensional interfaces inherent a fully strategic and tactical immersion. This is due, primarily, with some primitive interface, what made, usually in the form of technological schemes, with a possible animation. 3D interfaces allow the operator to feel activity on the sensory, spatial, emotional and psychological levels. The possibilities of narrative immersion is limited due to the lack of exciting narrative effects. 


\section{http://atbp.onaft.edu.ua/}

Table 4 - The types of dives in different interfaces of simulators

\begin{tabular}{|l|l|}
\hline Interfaces of simulators & Types of dives \\
\hline 2D & $\bullet$ Strategic \\
& $\bullet$ tactical \\
& less so: \\
& $\bullet$ narrative \\
\hline $3 \mathrm{D}$ & $\bullet$ tactical \\
& $\bullet$ strategic \\
& $\bullet$ emotional \\
& $\bullet$ touch \\
& $\bullet$ spatial \\
& $\bullet$ psychological \\
& less so: \\
& $\bullet$ narrative \\
\hline
\end{tabular}

For all the appeal of a 3D simulator, it should be noted his vulnerable side. Absolute realism and accuracy of the 3D interface is controversial. It's just impossible because of the limitations of the approach. There will always be a sense of artificiality and, as a consequence, there is a psychological sense of the game situation. Although this gives the student more motivation to learn, it reduces the sense of responsibility, is so necessary in the real work place [7]. ]. In addition, a significant drawback can be the cost of such equipment. Precision interfaces have bought the huge cost of system development and support. However, as noted earlier, work on the creation of such simulators is in full swing and gaining momentum.

We will consider the development of a 3D simulator of the operator of the press granulator.

The goal of this project is the improvement of economic efficiency of production of the granulated compound feed by improving the professional skills of operators of the press granulator. To achieve this objective, the solution of the complex problem:

- a visual representation of the production facility;

- providing training and improvement of professional skills of workers without economic risks of the enterprise;

- the use of interactive industrial machine;

- simulated abnormal and emergency situations in a virtual environment.

For the implementation of the simulator was taken a real production facility, was carried out the data collection: technical documentation, technological process description, equipment specification. In Fig. 1 shows a diagram of the technology development of the simulator.

Take a closer look at the stages of development.

1. Statement of the problem. At this stage, is formulated the purpose of the simulator, defined methods of problem solving, assesses the effectiveness of the algorithm, describes the requirements for devices that will use software developed software.

2. Analysis the task. Here more details are worked out initial data suggested their implementation in the developed simulator. Subsequently created a mathematical model of technological processes and applied equipment using block diagrams on a pre-prepared formalized description of different scenarios of operation of the virtual machine.

3. Development of solution algorithms. The developed application has a large number of scenarios of the press-granulator, each of which can be implemented via software in a variety of ways, so at this stage there is the choice of the optimal algorithms.

4. Designing the structure of the program. We develop detailed models of the program containing information about the hierarchy of subroutines, and methods of interaction with the user, storing information, etc.

5. Graphics simulator. At this stage also defines the General style of graphic design of the simulator, are requirements to individual elements, taking into account existing control systems of technological processes for more efficient assimilation of information, development of 3D models of process units and other elements of the system. For these purposes, used 3ds Max and the tools for working with the user interface of graphics engine Unity $3 \mathrm{~d}$.

6. Encoding. At this stage is coding the program, using materials obtained in the previous stages. Development environment - a program Unity3D, which has a built-in language support high-level programming C\#.

7. The testing and debugging. This step is necessary for finding and eliminating code errors and testing of various scenarios of user interaction with the simulator to avoid those situations when the program finds solutions for improper use [8].

The developed simulator will provide the opportunity to teach both students and retaining the already established operators of the press granulator. It is intended to develop many of the scenarios applicable for industrial situations: starting, stopping, and maintaining the operating mode detection and Troubleshooting.

In addition, it is planned to develop simulation of emergency situations, which will be a certification test the student all his knowledge and skills gained in the implementation of training programs. This simulator, in contrast to training programs must have the following features:

- the absence of any hints on the graphical user interface; 


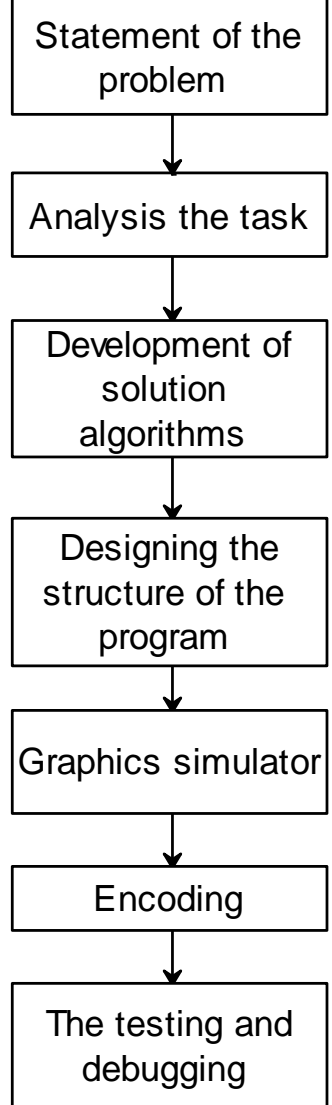

Fig. 1 - Development technology of simulator

- emergency randomly generated in each run of the simulator;

- there is no margin for error.

The simulator will allow you to test and hone their skills, simulating a real object. The employee who uses the simulator, must detect and correct the cause of the problem. Every time faults are randomly generated and can appear after some time after starting the simulator. The purpose of this algorithm is to develop the vigilance of the worker, his rational assessment of the situation, proper and timely corrective action. In case of an error on the part of the operator of the simulator stops and displays information about the current session. It specifies the allowed operator error, a fault in a running session, comments on how to fix it.

\section{Referenses}

[1] Tcherezov K. M., "Razrabotka kompyuternyih imitatorov tehnologicheskih protsessov i oborudovaniya predpriyatiy neftegazovoy otrasli", Ph.D. dissertation, Tyumensk. gos. neftegaz. univ., Tyumen, Russia, 2011.

[2] Gurdzibeeva A. R., "Issledovanie i razrabotka metodov i algoritmov imitatsionnogo modelirovaniya dlya trenazherov operatorov slozhnyih ob'ektov", Ph.D. dissertation, Severo-kavkazsk. gorno-metallurgich. inst., Gos. tehn. un-t, Vladikavkaz, Russia, 2004.

[3] V. M. Dozortsev "The World market of computer simulators for training operators: trends, challenges, forecasts," Automation in industry, no. 2, pp. 17-20, 2016;

[4] Operator Training Simulation Global Market Research Study. Market Analysis and Forecast through 2017. ARC Advisory Group. 2012.

[5] E. Adams (2004, July 9). "Postmodernism and the Three Types of Immersion". Gamasutra [Online]. Available: http://www.gamasutra.com/view/feature/130531/the_designers_notebook_.php. [Accessed: April 20, 2017];

[6] S. Björk and J. Holopainen, "Game and design patterns," The game design reader, pp. 410-437, 2006;

[7] Novichkov A. Yu. Interface of the field operator in a computer simulator: 3D immersion or 2D panorama? / Novichkov A. Yu., Frolov A. I., Pogorelov, V. P., Dozortsev V. M / - www.URL: https://www.researchgate.net/publication/305404955_Interfejs_polevogo_operatora_v_komputernom_trenazere_3D_po gruzenie_ili_2D_panorama

[8] E. G. Yukhin, et al., "Development of a virtual trainer-simulator of operation of the tubular furnace to improve the professional skills of employees of enterprises of oil and gas industry," Fundamental research, no. 12-5, pp. 970-974, 2015. 


\section{Література}

[1] Черезов К.М. Разработка компьютерных имитаторов технологических процессов и оборудования предприятий нефтегазовой отрасли : дис. ...канд. техн. наук : 05.02.22 / Черезов Кирил Михайлович ; М-во освіти і науки Рос. Федерації, Тюменськ. держ. нафтогаз. ун-т. - Тюмень, 2011. - $141 \mathrm{c.}$

[2] Гурдзибеева А.Р. Исследование и разработка методов и алгоритмов имитационного моделирования для тренажеров операторов сложных объектов : дис. ...канд. техн. наук : 05.13.01 / Гурдзибеева Алена Руслановна ; М-во освіти і науки Рос. Федерації, Північно-кавказьк. гірничо-металург. ін-т, 2004. - 188 с.

[3] Dozortsev V. M. The World market of computer simulators for training operators: trends, challenges, forecasts / V. M. Dozortsev // Automation in industry. - 2016. - № 2. - C. 17-20.

[4] Operator Training Simulation Global Market Research Study : Market Analysis and Forecast through 2017. - ARC Advisory Group, 2012.

[5] Adams E. Postmodernism and the Three Types of Immersion. Gamasutra [Electronic resource]. Access mode: http://www.gamasutra.com/view/feature/130531/the_designers_notebook_.php. - Дата звернення: 20.04.2017. Назва з екрану.

[6] Björk S. Game and design patterns / S. Björk, J. Holopainen // The game design reader. - 2006. - C. $410-437$.

[7] Novichkov A.Yu. Interface of the field operator in a computer simulator: 3D immersion or 2D panorama? [Electronic resource] / A.Yu. Novichkov, A.I. Frolov, V.P. Pogorelov, V.M. Dozortsev. - Access mode: www.URL: https://www.researchgate.net/publication/305404955_Interfejs_polevogo_operatora_v_komputernom_trenazere_3D_po gruzenie_ili_2D_panorama. - Назва з екрану.

[8] Yukhin E. G. Development of a virtual trainer-simulator of operation of the tubular furnace to improve the professional skills of employees of enterprises of oil and gas industry / E. G. Yukhin [et al.] // Fundamental research. - 2015. №12-5. - C. 970-974.

\section{ВНИМАНИЮ АВТОРОВ ЖУРНАЛА! ТРЕБОВАНИЯ К СТРУКТУРЕ И ОФОРМЛЕНИЮ СТАТЕЙ}

\section{ТРЕБОВАНИЯ К ТЕКСТОВОМУ ФАЙЛУ}

Поля со всех сторон - 20 мм. Шрифт - Times New Roman, 10 пунктов (кроме заголовка), интервал одинарный, выравнивание - по ширине. Абзацы в тексте - 0,5. Не добавлять интервал между абзацами одного стиля. Отражать абзащы пробелами и табулящией - запрещается!

УДК - в левом верхнем углу страницы.

Заголовок статьи печатается по центру строки заглавными буквами полужирным шрифтом на языке статьи и отдельно обязательно на английском языке, размером 18 пунктов. Переносы слов в заголовке не допускаются.

Фамилии и инициалы авторов - после заголовка (через 1 интервал в 10 пт) на языке статьи и отдельно обязательно на английском языке с указанием ученой степени и звания. Желательно указывать также свой ORCID номер.

Название организации (без сокращений), город и e-mail автора - в следующей строке по центру полужирным шрифтом.

Аннотация - через один интервал в 10 пт. курсивом (на языке статьи объемом не менее 1900 символов без пробелов и соответствующий перевод на английском языке), а с новой строки обычным шрифтом - ключевые слова на языке статьи и на английском языке (не более 8).

Текст статьи - через один интервал в 10 пт. после ключевых слов.

Литература - полужирным шрифтом, перед ним интервал в 10 пт. Список источников оформляется согласно «ДСТУ 8302:2015. Бібліографічне посилання. Загальні положення та правила складання». Дополнительно ниже приводится слово «References» и тот же список литературы, но в романском алфавите (латиница), оформляется согласно Electrical Engineering Citation Style (http://www.journal-atbp.com/autors). Количество Интернет источников в списке литературы не может превышать $40 \%$ всего списка.

Рисунки, диаграммы и графики - черно-белым в любом графическом редакторе, который поддерживает форматы bmp, gif, tiff, pcx, jpeg, dwg, cdr, mcd. Допускается использование диаграмм и графиков Microsoft Excel в градациях черного. Рисунки нумеруют и подписывают по центру строки полужирным шрифтом без точки в конце, расшифровку обозначений делают перед названием рисунка курсивом. Перед и после названия рисунка интервал в 6 пт.

Формулы набирают в редакторе Microsoft Equation 3.0 и центрируют. Нумеруют только те формулы, на которые есть ссылки. Номера формул указывают в круглых скобках и выравнивают по правому краю страницы. Центрирования формул и выравнивание номеров выполняется табуляцией (но не пробелами!) Параметры настройки: переменная - курсив, другие - обычные, размеры (пт.): обычный - 10; крупный индекс - 7; мелкий индекс - 6; большой символ - 16; мелкий символ - 10.

Таблицы, как правило, располагают под текстом после первого упоминания или на следующей странице. Название таблицы указывают через короткое тире после номера по центру строки полужирным шрифтом без точки в конце. До и после названия таблицы, а также перед абзацем, следующего после таблицы, устанавливают интервалы в 6 пт. 